\title{
(5)
}

AL-DZIKRA

Jurnal Studi Ilmu Al-Qur'an Dan Al-Hadits http://ejournal.radenintan.ac.id/index.php/al-dzikra Volume 12, No. 1, Juni Tahun 2018, Halaman 1 - 20

DOI://dx.doi.org/10.24042/al-dzikra.v12i1.2923

\section{DIMENSI KONTEKSTUAL DALAM TAFSIR HIZBUT TAHRIR INDONESIA}

\author{
Marjan Fadil \\ STAI Nurul Iman Parung \\ marjanfadil@gmail.com \\ Muhammad Ainun Najib \\ IAIN Tulungagung \\ muhammadainunajib@gmail.com
}

\begin{abstract}
This article wants to show that Hizbut Tahrir Indonesia as Islamic political movement not only understand al-Qur'an literally but also contextually, by watching their actions. This is an objection to the opinion that the radical movement always understand the religious texts literally. This article uses any Taqiyyuddin anNabhani's writings and other Hizbut Tahrir thinker as prime resources. From this research proved that generally HTI understands the text of Qur'an and hadith literally, but in the case of khilafat concept, they understand it contextually.
\end{abstract}

\section{Abstrak}

Tulisan ini ingin menunjukkan bahwa Hizbut Tahrir Indonesia (HTI) sebagai sebuah gerakan Islam yang lebih kepada aliran politik di Indonesia tidak hanya memahami al-Qur'an secara tekstual, namun juga melihat dari sisi kontekstual dengan aksiaksi yang mereka lakukan. Hal ini juga membantah anggapan bahwa aliran fundamentalis Indonesia seringkali berorientasi 
tekstual dalam memahami teks-teks keagamaan. Tulisan ini menggunakan berbagai karya Taqiyuddin al-Nabhāni sebagai pendiri Hizbut Tahrir dan tokoh-tokohnya yang lain, serta berbagai aksi-aksi yang mereka lakukan sebagai sumber primer. Dari kajian ini ditemukan fakta bahwa HTI secara umum menafsirkan al-Qur'an maupun Hadis secara literal teks, akan tetapi mereka juga menggunakan penafsiran kontekstual dalam penerapan Khilafah.

Kata Kunci: Contextual, Tafsir, Hizbut Tahrir Indonesia.

\section{A. Pendahuluan}

Tradisi penafsiran teks al-Qur'an sebenarnya telah dimulai semenjak al-Qur'an itu ada. Mengenai hal ini al-Qur'an menjelaskan bahwa salah satu fungsi Nabi Muhammad adalah sebagai penjelas al-Qur'an ${ }^{1}$. Permasalahan muncul ketika perdebatan terjadi apakah al-Qur'an ditafsirkan seluruhnya atau tidak sedangkan Nabi Muhammad telah meninggal dunia pada masa itu dan di sisi lain permasalahan umat yang semakin berkembang seiring berkembangnya Islam ke berbagai daerah menjadikan kebutuhan penafsiran al-Qur'an juga ikut berkembang. Sehingga menuntut akan adanya pemahaman yang bisa mengakomodasi problematika kehidupan sepanjang waktu.

Problematika utama dalam dunia tafsir adalah adanya kesenjangan antara produk tafsir yang hadir dan kemudian dikonsumsi oleh masyarakat. ${ }^{2}$ Salah seorang tokoh tafsir yang muncul berkaitan dengan pemahaman tafsir ini adalah Muhammad Abduh, ia mengkritik penafsiran-penafsiran klasik yang hanya berdebat dalam kajian kebahasaan dan hukum saja. Hal ini pula menurut penulis merupakan istilah tafsir yang kemudian muncul dengan istilah tafsir tekstual.

Disamping kegelisahan tersebut, usaha untuk mendialogkan al-Qur'an sebagai teks dengan masalah sosial kemanusiaan menjadi semangat tersendiri dalam kajian tafsir. Hal ini dikarenakan bahwa al-Qur'an yang meskipun turun pada masa lalu, namun mengandung nilai-nilai yang universal dan relevan untuk setiap zamannya (șălih

${ }^{1}$ Lihat QS. Al-Nahl [16]: 44.

${ }^{2}$ Lilik Ummi Kaltsum, Mendialogkan Realitas dengan Teks (Surabaya: PMN, 2010), h. 1. 
li kulli zamān wa makān). Berangkat dari ini semua tergambar bahwa al-Qur'an selalu terbuka terhadap penafsiran-penafsiran dan menerima perbedaan penafsiran. ${ }^{3}$ Penafsiran-penafsiran yang kemudian muncul pada era modern diharapkan bisa menjadi penafsiran yang mampu menjawab kegelisahan masyarakat dengan memperhatikan konteks realitas masyarakat sekarang.

Beralih dari pandangan terkait dengan pemahaman teks keagamaan tersebut, muncul anggapan bahwa kekerasan-kekerasan panjang hebat di berbagai belahan dunia juga disebut-sebut didalangi oleh sekte-sekte Islam yang dianggap berfikir konservatif. Tidak jarang dalam beberapa hal masyarakat dunia seperti Eropa dan Amerika menuduh Islam sebagai sebab utama di balik aksi-aksi kekerasan tersebut. Tuduhan itu secara serampangan mereka pahami melalui ajaran-ajaran Islam yang dianggap tidak relevan lagi terhadap ajaran demokrasi pada abad ini. Nicolaos Van Dam (Duta Besar Belanda untuk Indonesia) jelas-jelas menyebutkan bahwa Islam dianggap sebagai agama yang dicap buruk di Belanda, hal ini dikarenakan beberapa hukum dalam Islam seperti potong leher, potong tangan, hukuman cambuk, kebolehan poligami, menikahi gadis dibawah umur dan jihad dengan kekerasan. ${ }^{4}$

Pada perkembangan selanjutnya, terlepas dari benar atau tidaknya pemahaman tersebut, tekstualitas penafsiran keagamaan yang sering dituduh sebagai penyebab umat beragama menjadi lebih eksklusif dan lebih keras perlu ditinjau kembali kebenarannya. Sehingga tidak menimbulkan kesan negatif bahwa penafsiran klasik atau tradisional itu buruk dan penafsiran modern yang terbaik. Contoh yang dikemukakan oleh Abdullah Saeed tentang pemahaman tekstualis atau tradisonalis adalah kelompok Salafi. Hal ini dikarenakan penafsiran-penafsiran mereka yang cenderung hanya berkutat dikajian kebahasaan. Namun, terlepas dari itu semua M. Quraish Shihab juga berkomentar bahwa dalam menafsirkan alQur'an seperti ulama salaf tidak sepenuhnya benar tetapi dengan menghapus penafsirannya juga cenderung akan berdampak negatif. ${ }^{5}$

${ }^{3} \mathrm{U}$ Syafrudin, Paradigma Tafsir Tekstual dan Kontekstual: Usaha Memaknai Kembali Pesan Al-Qur'an (Yogyakarta: Pustaka Pelajar, 2009), h. 5.

${ }^{4}$ Nicolas Van Dam, Islam dalam Pandangan Barat (Republika, 2009)

${ }^{5}$ M. Quraish Shihab, Membumikan al-Qur'an: Fungsi dan Peran Wahyu dalam Kehidupan Masyarakat (Bandung: Mizan, 2009), h. 141. 
Salah satu kelompok Islam yang juga berkembang di Indonesia disamping Salafi adalah HTI (Hizbut Tahrir Indonesia). HTI berkembang pesat di Indonesia sebagai salah satu organisasi yang bergerak demi ajaran Islam. Mereka menilai bahwa dunia Islam saat ini mengalami kemerosotan hebat. Meskipun telah dilakukan berbagai upaya untuk membangkitkan Islam, hal itu tidak membuahkan hasil sama sekali. Mereka beranggapan, sebab kemunduran umat Islam ini tidak lain dikarenakan oleh lemahnya pemahaman umat terhadap Islam yang amat parah. menurut Hizbut Tahrir Sebab utama hal itu adalah ketiadaan satu kekuasaan politik umat yang melingkupi seluruh bangsa (khilāfah Islāmiyah). ${ }^{6}$ Dengan kata lain Hizbut Tahrir bergerak dalam rangka mengembalikan ajaran Islam yang murni, khususnya di bidang politik.

\section{B. Penafsiran Tekstual dan Kontekstual}

1. Penafsiran Tekstual

Permulaan penafsiran yang muncul adalah penafsiran yang menggunakan riwayat-riwayat serta hadis-hadis Nabi sebagai penjelas al-Qur'an. Penafsiran seperti ini disebut juga sebagai penafsiran tradisional $^{7}$ atau Nasr Hamid Abu Zaid menjelaskan bahwa penafsiran seperti ini disebut juga penafsiran yang berorientasi kepada teks. Permasalahan muncul ketika dikatakan bahwa penafsiran seperti ini tidak cocok lagi digunakan sebagai penafsiran untuk zaman sekarang. Penafsiran klasik-tradisional disebut juga sebagai penafsiran yang menekankan pada metode analitik yang bersifat atomistik dan parsial. ${ }^{8}$

Istilah "Tafsir Tekstual" yang muncul belakangan sebenarnya tidak dikenal dalam peristilahan bahasa Arab. ${ }^{9}$ Namun, secara esensi penafsiran seperti itu telah tergambar dalam

${ }^{6}$ Taqiyuddin an-Nabhāni, Mafāhim Hizb al-Tahrir, pent. Abdullah (Jakarta Selatan: Hizbut Tahrir Indonesia, 2007), h. 5.

${ }^{7}$ Abdullah Saeed, Interpretating the Qur'an: toward a contemporary approach (New York: Routledge Taylor \& Francis Group, 2005), h. 42.

${ }^{8}$ Abdul Mustaqim, Epistemologi Tafsir Kontemporer (Yogyakarta: LkiS, 2010), h. 63. Salah satu bentuk tafsir model ini adalah penafsiran al-Qur'an dengan menggunakan hadits Nabi Muhammad. Penafsiran ini memiliki banyak kelebihan. Namun juga terdapat beberapa kelemahan. Lihat Ahmad Khoirul Fata, "Kekuatan dan Kelemahan Tafsir al-Qur'an bi al-Sunnah" Farabi, Vol. 13 No 2 (2016), h. 241-256.

${ }^{9}$ U Syafrudin, Paradigma Tafsir Tekstual..., h. 38. 
penafsiran-penafsiran sebelumnya, seperti tafsir tahlīlì, mujmāl, muqaran dan mungkin juga terdapat dalam tafsir maudu'i. Apabila dilihat dari segi kebahasaan, tekstual merupakan kata sifat dari text yang berarti segala bentuk materi dari tulisan ${ }^{10}$. Keterangan ini mungkin cukup menjelaskan bahwa teks merupakan segala jenis simbol yang tertulis. Artinya, apapun bentuk tulisan itu baik itu bisa dipahami ataupun tidak, disebut dengan teks. Artinya, jika dipahami dalam tafsir berarti segala jenis penafsiran yang mengedepankan teks sebagai sumber penafsiran.

Jika ditinjau kembali mengenai makna tekstual diatas kemudian dikaitkan dengan sebuah metode penafsiran akan menimbulkan sedikit kebingungan. Misalnya, ketika sebuah teks membutuhkan teks lain sebagai sebuah penafsiran, apakah hal itu disebut sebagai tafsir tekstual atau tidak, Penulis meyakini bahwa permasalahan ini merupakan penafsiran tekstual, jika permasalahan ini dilihat dari struktur bahasanya. Abdullah Saeed juga menegaskan bahwa penafsiran tekstual adalah penafsiran yang hanya menekankan kepada makna teks dalam memahami alQur'an. ${ }^{11}$ Sebagai contoh, ketika seorang lelaki diperbolehkan menikahi empat orang istri itu tidak bisa dibantah, tentang mengapa ayat tersebut diturunkan atau hal-hal yang melatarbelakangi ayat tersebut diturunkan tidaklah penting.

2. Penafsiran Kontekstual

Al-Qur'an yang merupakan sumber ajaran umat Islam, menduduki posisi pertama dalam ajaran Islam. Sehingga bahasa Arab berada di posisi paling tinggi sebagai alat untuk memahami alQur'an. Hal seperti inilah yang dilakukan dalam penafsiran di periode awal. Agar al-Qur'an menjadi petunjuk yang universal. Pada perkembangan selanjutnya bahasa arab tidak dijadikan sebagai satu-satunya alat dalam penafsiran. Namun, menjadikannya sebagai suatu pelengkap agar sebuah penafsiran itu lebih komprehensif. ${ }^{12}$

Istilah kontekstual muncul setelah istilah tafsir tekstual muncul. Jika dilihat dari segi kebahasaan konteks berarti situasi

${ }^{10}$ Oxford University, Oxford Learner's Pocket Dictionary (Oxford University Press, 2008), h. 459.

${ }^{11}$ Abdullah saeed, Interpretating the Qur'an..., h. 3.

${ }^{12}$ Amina Wadud, Qur'an and Women: reading the sacred text from the women's perspektive (Oxford University Press, 1999), h. xii. 
ketika sebuah kejadian terjadi. ${ }^{13}$ Jika konsep "kontekstual" dipahami dalam konteks penafsiran berarti penafsiran yang melihat situasi atau keadaan dimana teks tersebut muncul. Pertanyaan muncul berkenaan dengan pemahaman seperti ini. Ketika orientasi yang mempengaruhi dimana teks itu muncul merupakan inti dari penafsiran kontekstual, apakah teks-teks yang ada tersebut juga mempengaruhi teks-teks yang lain muncul. Sehingga dapat dikatakan bahwa konteksnya dijelaskan oleh teks lain juga termasuk pemahaman kontekstual.

Gagasan tentang tafsir kontekstual juga merupakan hal baru dalam ranah kajian tafsir. Fazlur Rahman disebut-sebut sebagai penggagas tafsir kontekstual ${ }^{14}$. Hal yang melatar belakangi Fazlur Rahman dalam memunculkan penafsiran seperti ini menurut U. Syafrudin adalah disebabkan oleh kecenderungan orang-orang dalam memahami al-Qur'an secara ayat per-ayat bahkan kata per kata, sehingga mengakibatkan ketidakmampuan dalam menangkap maksud teks al-Qur'an secara lebih konprehensif. Dengan demikian, Abdullah Saeed menyimpulkan bahwa penafsiran kontekstual lebih melihat kepada sisi politik, sosial, sejarah, budaya dan konteks ekonomi saat teks itu muncul. ${ }^{15}$

Dalam kaitan ini, konsep konteks juga dimaksudkan sebagai situasi serta kondisi yang mengelilingi seorang pembaca. ${ }^{16} \mathrm{Jadi}$, dapat dikatakan bahwa kontekstual adalah situasi-situasi yang mengelilingi pembaca baik itu situasi sosial, lingkungan, politik, psikologis dan sebagainya dimana seorang mufasir itu mengeluarkan produk tafsirnya. Jika ditarik dalam kajian tafsir, tafsir kontekstual yaitu penafsiran yang lebih menekankan kepada sosio-historis dimana al-Qur'an itu muncul (bisa jadi itu asbāb alnuzūl) dan konteks penafsiran selanjutnya. ${ }^{17}$ Meski mendapat respon positif dari banyak sarjana muslim, namun tafsir kontekstual juga harus diterapkan secara hati-hati. Tidak boleh secara serampangan dan semena-mena karena kompleksitas konteks yang melingkupi sebuah teks saat diproduksi, atau pun saat teks itu

${ }^{13}$ Oxford University, Oxford Learner's Pocket Dictionary ..., h. 93.

${ }^{14}$ U Syafrudin, Paradigma Tafsir Tekstual..., 43.

${ }^{15}$ Abdullah saeed, Interpretating the Qur'ān..., h. 3.

${ }^{16}$ Morgan L. Walters, The Holt Intermediate Dictionary of American English (New York: Holt, Rinehart and Winston, Inc, 1966), h. 169.

${ }^{17}$ Abdullah saeed, Interpretating the Qur'ān..., h. 3. 
dipahami oleh pembaca. Karena kesemena-menaan dalam penerapan tafsir kontekstual dapat mengancam otentisitas agama itu sendiri. ${ }^{18}$

\section{Hizbut Tahrir Indonesia (HTI) \\ 1. Sejarah HTI}

Gerakan-gerakan Islam model baru banyak yang muncul lebih jelas terlihat pada saat masa reformasi, meskipun perkembangan awal mereka sudah sejak era Orde Baru. Hal ini dapat dipahami karena pasca Orde Baru kebebasan bersuara lebih terbuka. Seperti dalam menyampaikan ide-ide tentang syariat Islam yang gencar-gencarnya dilakukan oleh organisasi-organisasi Islam di Indonesia. Mereka main berani menyuarakan penegakan syari'at Islam atau bahkan negara berdasar Islam di Indonesia.

Hizbut Tahrir pada awalnya disebut dengan Hizb al-Tahrir al-Islami yang berasal dari bahasa Arab bermakna Partai Pembebasan Islam. Partai ini didirikan pada tahun 1952 di al-Quds Palestina. ${ }^{19}$ Pendirinya adalah Taq̄i al-Dīn al-Nabhāni (1905-1978) yang kemudian dikenal di Indonesia dengan nama Syekh Taqiyyuddin al-Nabhani. Ia adalah seorang ulama, mujtahid, hakim di pengadilan Palestina dan lulusan al-Azhar Mesir. Gelar AlNabhani dinisbahkan kepada kabilah Bani Nabhan yang merupakan orang Arab yang tinggal di sahara Palestina. Setelah menempuh pendidikan di Mesir ia kembali ke Haifa untuk mengajar dan berprofesi sebagai hakim di berbagai pengadilan. Pada tahun 1948 dia pindah ke Beirut bekerja di pengadilan di Bait al-Maqdis alQuds. Dia kemudian menjadi pengajar di Universitas Islam di Oman Yordania.

Pada tahun 1950 An-Nabhani menerbitkan buku yang berjudul The Treatise of the Arab, karya ini menggambarkan gerakan pembentukan negara Islam di wilayah Arab dan non-Arab. Setelah membentuk Hizbut Tahrir ia menerbitkan beberapa buku dan terorganisir yang ditujukan bagi demonstran di seluruh Yordania, Suriah dan Lebanon dalam rangka meningkatkan karir

${ }^{18}$ Lihat Ahmad Khoirul Fata, "Pembaharuan Hukum Islam dan Problem Otentisitas Agama," Ijtihad, Vol. 13, No. 2 (2013), h. 163-178.

${ }^{19}$ Lihat http://id.wikipedia.org/wiki/Hizbut_Tahrir, diakses pada 12 Oktober 2014, lihat juga http://www.mykhilafah.com/hizbut-tahrir, diakses pada 12 Oktober 2014. 
politiknya. ${ }^{20}$ Setelah kematiannya, ia digantikan oleh Sheikh Abdul Qadim Zallum. Kepemimpinan Zallum terhadap Hizbut Tahrir berlangsung selama 13 tahun, berakhir dengan kematiannya pada tahun 2003. Pandangan kedua tokoh ini dapat dilihat dari buku-buku yang sudah diterbitkan Hizbut Tahrir. Sepeninggal pemimpin kedua, sejak tahun 2003, Hizbut Tahrir dipimpin oleh Syekh Atha' Abu Rasytah. Beliau adalah adalah pemimpin nomor satu dalam struktur Hizbut Tahrir sekarang ini secara internasional.

Sejak diselenggarakan konferensi Internasional di Istora Senayan yang dihadiri oleh tokoh-tokoh Hizbut Tahrir Internasional maupun nasional serta tokoh Islam dari kelompok lain. Hizbut Tahrir resmi melakukan aktifitas organisasinya yang kemudian dikenal dengan nama Hizbut Tahrir Indonesia (HTI). Hizbut Tahrir mulai masuk ke Indonesia pada tahun 1980-an dengan merintis dakwah di kampus-kampus besar seluruh Indonesia. Dalam lingkup Indonesia, Humas HTI dipimpin oleh Ismail Yusanto. HTI merupakan organisasi mandiri, dimana mereka mendapatkan dana dari para simpatisan. Mereka juga secara tegas menolak dana bantuan dari Pemerintah, malahan secara tegas mengharamkannya. $^{21}$

HTI sejak awal memang didesain sebagai organisasi politik. Tetapi berbeda dengan organisasi politik lainnya di Indonesia. Ia tidak secara formal mendaftarkan organisasinya sebagai partai politik yang ikut dalam pemilu. Hal ini menurut salah salah seorang aktivisnya menyebutkan bahwa banyaknya partai Islam justru membingungkan masyarakat untuk memilih. Oleh karena itu mereka tidak menjadi kelompok yang masuk kedalam partai politik. Pada era 1990-an ide-ide dakwah HTI merambah ke masyarakat melalui berbagai aktivitas dakwah di pejabat perusahan dan ke rumah-rumah pada akhirnya. ${ }^{22}$ Pasca dikeluarkannya Peraturan Pemerintah Pengganti Undang-undang (Perppu) oleh Presiden Joko

${ }^{20}$ Mateen Siddiqui, The Doctrine of Hizb ut-Tahrir, Conference Report The Challenge of Hizb ut-Tahrir: Deciphering and Combating Radical Islamist Ideology (The Nixon Center, 2004), h. 1.

${ }^{21}$ Afadlal dkk, Islam dan Radikalisme di Indonesia (Jakarta: LIPI Press, 2005), h. 266.

2014.

${ }^{22}$ http://www.mykhilafah.com/hizbut-tahrir, diakses pada 12 Oktober 
Widodo, badan hukum HTI pun dicabut oleh pemerintah. Dan HTI kini bergerak secara bawah tanah.

\section{Pemahaman HTI}

\section{a. Landasan berdirinya Khilafah}

Hizbut tahrir merupakan sebuah organisasi Islam yang bergerak atas petunjuk dari Allah yang merujuk pada Q.S. Ali Imran:104. Hizbut Tahrir bermaksud ingin membangkitkan kembali Islam dari kemerosotan yang amat parah, membebaskan umat dari ide-ide, sistem perundang-undangan dan hukum-hukum kufur serta membebaskan mereka dari cengkeraman dominasi pengaruh negara-negara kafir. Hizbut Tahrīr juga ingin membangun kembali Daulah Khilafah Islamiyyah di muka bumi, sehingga hukum yang diturunkan Allah SWT dapat diterapkan kembali.

Menurut HTI berbagai upaya umat Islam untuk membangkitkan umat Islam dari kemerosotan telah gagal dikarenakan tiga hal: pertama: Pemahaman yang begitu lemah terhadap fikrah Islāmiyah (konsep Islam). Kedua: tidak adanya pemahaman țariqah Islämiyah (metode penerapan) yang benar. ${ }^{23}$ HTI menyatakan bahwa, agar kembalinya umat Islam ke masa kejayaannya adalah dengan jihad yang dilakukan oleh negara. Untuk itu negara harus menjadi pondasi agar terbentuknya Islam yang kokoh lagi. Umat Islam sekarang terlalu disibukkan dengan persoalan fikrah (konsep) saja, dan mengabaikan țariqah (metode operasionalnya). Mereka hanya sibuk membahas tentang syari'ah saja, baik itu shalat, puasa, nikah dan talak. Sedangkan, hukum yang berkaitan dengan jihad, ghanimah, hukum-hukum menyangkut Khilafah dan sebagainya diabaikan.

Sisi lain yang juga dikritik oleh HTI adalah penafsiran di tengah-tengah masyarakat di penghujung abad 19 M. Penafsiranpenafsiran di periode ini sudah tidak sesuai dengan isi kandungan naș-nas al-Qur'an lagi. HTI beranggapan bahwa penafsiran yang memiliki tujuan agar sesuai dengan kondisi masyarakat pada saat ini merupakan suatu kesalahan. Justru masyarakatlah yang harus dirubah agar sesuai dengan Islam. ${ }^{24}$ Hal pertama yang dilakukan

${ }^{23}$ Taqiyuddin an-Nabhaāni, Mafaāhim Hizb al-Tahrī̄r, pent. Abdullah (Jakarta Selatan: Hizbut Tahrir Indonesia, 2007), h. 6.

${ }^{24}$ Ibid., h. 10. 
oleh HTI adalah berdakwah, hal ini tergambar jelas dalam bukunya al-Daulah al-Islāmiyyah karya Taqiyuddin al-Nabhāni.

Saat-saat terakhir perkembangan pemerintahan Islam adalah ketika kekhalifahan Usmaniyyah runtuh dan diganti dengan sistem Republik oleh Kemal Atatturk, seorang bapak nasionalisme sekuler Turki. Sejak saat itu model pemerintahan Islam yang selama ini dibangun diganti dengan sistem pemerintahan modern meskipun mayoritas penduduknya beragama Islam. Berkaitan dengan itu semua, ide utama yang menjadi perhatian HTI adalah ide menyebarkan Islam ke seluruh penjuru dunia. Pertama-tama ialah menentukan satu tempat sebagai pusat dakwah Islam kemudian dengan satu Daulah Islam tersebut disebarkan ke seluruh dunia. Demi terwujudnya hal tersebut HTI memulainya dengan pembangunan di wilayah Arab kemudian berlanjut secara sendirinya hingga penjuru dunia. ${ }^{25}$

HTI mengklaim bahwa kekhalifahan memiliki sisi positif yang lebih baik dibandingkan dengan bentuk negara-negara yang ada di zaman modern sekarang ini. Bentuk negara modern sekarang ini lebih mensub-ordinasi agama atas kepentingan nasionalnya. Kuatnya kemauan untuk menghidupkan kembali kekhalifahan juga disebabkan oleh oleh faktor upaya kontekstualisasi atas ajaranajaran Islam. Artinya mereka juga beranggapan bahwa tidak adanya naș-naș al-Qur'an yang mengharuskan berdirinya Khalifah, tetapi kewajiban ini lebih didasarkan kepada pemahaman kontekstual mereka terhadap pesan al-Qur'an.

HTI menyebutkan bahwa umat Islam zaman sekarang ini berada dalam situasi yang tidak islami, yang disebabkan oleh pengaruh budaya Barat yang semakin merajalela di kalangan masyarakat dan berlakunya paham sekuler ${ }^{26}$ dalam pemerintahan. Berbagai pelembagaan hukum yang sekuler baik itu pidana maupun

${ }^{25}$ Taqiyuddin an-Nabhaāni, al-Takattu al-Hizbī, pent. Zakaria, Labib dkk (Jakarta Selatan: Hizbut Tahrir Indonesia, 2013), h. 10-11.

${ }^{26}$ Sekularisme muncul bersamaan dengan modernisasi masyarakat Barat. Paham ini lahir sebagai reaksi atas dominasi Barat Abad Pertengahan terhadap masyarakat Barat dengan basis epistemologis manusia sebagai pusat kebenaran. Karenanya sekularisme menjadi tantangan serius bagi kalangan agamawan. Lihat Ahmad Khoirul Fata dan S Mahmudah Noorhayati, "Sekularisme dan Tantangan Tantangan Pemikiran Islam Kontemporer," Madania, Vol 20, No 2 (2016), h. 215-228. 
perdata tidak membuahkan hasil yang signifikan terhadap kemajuan masyarakat. Karena itu mereka meyakini bahwa perubahan kearah yang lebih Islami akan terbentuk dengan perubahan sistem politik. Salah seorang tokoh HTI menyebutkan bahwa untuk merubah masyarakat seperti itu adalah dengan merubah sistempolitiksekuler dengan sistem islami. Artinya, semua sistem pemerintah haruslah diatur dengan konsep syariat Islam.

Dalam konteks keindonesiaan, mereka berpendapat bahwa ideologi Pancasila tidak bisa disebut bedasarkan prinsip islami. Hal ini dikarenakan, aturan kenegaraan tidak melaksanakan totalitas ajaran Islam terhadap masyarakat. Menurut pandangan HTI khalifah adalah penguasa tertinggi dalam sebuah pemerintahan. Seorang Khalifah-lah yang akan memandu jalannya kehidupan masyarakat agar menjadi lebih baik. Seperti memimpin jihad dan melindungi Umat. Dakwah merupakan cara satu-satunya agar meraih kekhalifahan itu. Mereka menolak anggapan bahwa HTI menerima cara kekerasan. Mereka beranggapan bahwa cara untuk mendekati masyarakat bukanlah dengan mengangkat senjata, melainkan dengan dakwah secara terus-menerus. Secara kelembagaan HTI menekankan pentingnya penerapan syariat Islam yang ditopang oleh sebuah pemerintahan. Mereka berpendapat bahwa agama dan syariat tidak boleh dipisahkan. Penelitian dari LIPI menyebutkan bahwa kelompok HTI ini merupakan kelompok yang menganut paham integrasi antara agama dan Negara. ${ }^{27}$

Menurut HTI, ada empat hal yang secara prinsipil membedakan sistem politik Islam dengan sistem-sistem politik yang lain, ${ }^{28}$ yaitu:

${ }^{27}$ Lihat Afadlal dkk, Islam dan Radikalisme di Indonesia..., h. 267. Kecenderungan umat Islam terhadap hubungan agama dan negara terbagi kedalam tiga sikap; pertama, pendapat yang mengatakan bahwa agama dan negara itu berkaitan satu sama lain. Kelompok ini sering disebut dengan formalis. Aliran radikal sering dikaitkan dengan kelompok yang bersikap seperti ini. Meskipun hal itu tidak selalu benar. Kedua, membedakan antara agama dan negara. Kelompok ini menekankan agama berperan sebagai penentu moral dalam negara. Ketiga, kelompok yang beranggapan sekuler. Kelompok ini memandang bahwa agama dan Negara harus dipisahkan. Mereka menekankan agama sebagai keyakinan privasi manusia sedangkan Negara merupakan wilayah umum.

${ }^{28}$ Lihat Ibid., h. 270-271. 
1) Kedaulatan ada ditangan syara'. Dalam Islam yang berhak menentukan baik dan buruk adalah ketentuan syariat dari Allah SWT

2) Kekuasaan berada ditangan Umat. Khalifah yang merupakan unsur tertinggi dalam pemerintahan harus dipilih sesuai dengan tujuan Umat. Mereka menilai bahwa kekuasaan harus dibai'at oleh orang-orang yang terpercaya dalam masyarakat kemudian diakui atau dibai'at oleh umat sebagai Khalifah.

3) Khalifah yang ditunjuk hanya ada satu. Artinya tidak boleh adanya khalifah lain.

4) Khalifah memiliki otoritas untuk mengadopsi pendapat dari hukum syara' yang dijadikan sebagai undang-undang.

Pendapat tentang kekuasaan berada ditangan umat sesungguhnya tidak terlalu berbeda dengan prinsip pemerintahan demokrasi di Indonesia. Artinya, demokrasi dalam prakteknya juga mengusung kebebasan memilih bagi tiap individu dan setiap anggota masyarakat berhak memilih sesuai dengan keinginannya. Hal ini juga memberi kesan bahwa prinsip Islam tidak terlalu berbeda dengan prinsip dalam sila ke-empat pancasila. Dapat dikatakan bahwa HTI hanya percaya dengan hukum Allah. Oleh karena itu, kelompok ini mendukung paham monokrasi. Mereka menolak demokrasi dikarenakan demokrasi mengikuti suara mayoritas yang belum tentu kebenarannya. Seperti yang telah disebutkan sebelumnya bahwa HTI menolak kebenaran yang dilandaskan oleh pikiran semata. Baik atau buruk telah ditetapkan sesuai dengan shari'at agama. Misalnya perjudian, pelacuran dan penjualan minuman keras tidak dapat dibenarkan dengan alasan apapun meski itu telah disepakati mayoritas masyarakat. Hal tersebut harus melihat hukum Allah sebagai pengaturan tindakan.

Prinsip kewajiban penegakan khilafah merupakan suatu keniscayaan bagi HTI. Meskipun pandangan HTI mengharuskan berdirinya Khilafah, kelompok ini bukanlah penganut paham kekerasan dalam bertindak. Mereka beralasan bahwa untuk mengubah masyarakat tidak boleh dengan kekerasan fisik, melainkan dengan mengubah prinsip pandangan hidupnya. Mereka bertujuan ingin menegakkan agama Islam yang harmonis bagi semua pemeluk agama lain. Karena Islam yang ada di Indonesia ini mayoritas, mereka berupaya menuntut hak mereka sebagai kelompok mayoritas muslim dan menegakkan syari'at Islam di 
Indonesia. Upaya-upaya yang dilakukan HTI demi terciptanya khilafah adalah dengan berdakwah. Hal ini telah lama mereka lakukan baik dalam bentuk tulisan maupun lisan.

\section{b. Prinsip Penafsiran HTI}

HTI tidak menolak akan adanya ijtihad dalam penafsiran alQur'an, tetapi ijtihad haruslah bersumber dari naș-naș yang ada. Mereka menyebutkan bahwa fungsi akal adalah untuk memahami syara' bukan menjadikannya sebagai dalil. Mereka juga menegaskan bahwa hukum-hukum syara' yang berkaitan dengan ibadah, akhlak, makanan, dan pakaian tidak boleh dicari 'illat-nya. Mereka menolak gagasan menjadikan asas manfaat semata sebagai dasar terhadap suatu perbuatan. Seperti potongan ayat pada QS. AlBaqarah [2]: 275, yang artinya "Allah menghalalkan jual beli dan mengharamkan riba." Mereka menyatakan bahwa ayat ini tidak bisa dicari illat-nya karena telah dijelaskan oleh naș, sehingga tak ada ruang untuk berijtihad. Potongan ayat ini terlihat bahwa dalam memahami al-Qur'an, mereka cenderung memahami secara literal atau tekstual.

Argumen lain yang juga dilontarkan oleh HTI adalah tentang perbuatan baik atau buruk. Tidak ada ruang bagi akal untuk menentukan pilihan perbuatan itu baik atau tidak, Karena naluri manusia yang cenderung ingin melakukan sesuatu yang membuatnya senang adalah alamiah, sedangkan kesenangan itu merupakan perkara yang jelek menurut Islam. Sehingga dapat disimpulkan bahwa naṣ-naș Allah merupakan patokan dalam bersikap. Pergaulan antara lelaki dan wanita juga menjadi perhatian serius HTI. Hal ini dikarenakan banyaknya kemarahan anggota keluarga, perselisihan serta permusuhan di antara mereka yangdapat merusak tatanan umat Islam. ${ }^{29}$

Seperti yang telah disebutkan sebelumnya bahwa HTI sebagai sebuah organisasi Islam memliki visi menghidupkan kembali syari'at Islam dimuka bumi. Mereka memiliki prinsip bahwa untuk menghidupkan kembali syari'at Islam adalah dengan kembali memahami al-Qur'an dan Hadits sebagai kode etik dalam bersikap dan tingkah laku, serta menolak rasionalitas berlebihan yang keluar dari syari'at agama Islam.

${ }^{29}$ Taqiyuddin an-Nabhāni, al-Nizām al-Ijtimā’i fi al-Islām, pent. M. Nashir dkk (Jakarta Selatan: Hizbut Tahrir Indonesia, 2014), h. 10-12. 
Ayat-ayat yang sering dimunculkan dengan memahami secara literal tekstual adalah pada potongan surat al-Māidah [5] ayat 44, 45, dan 47:

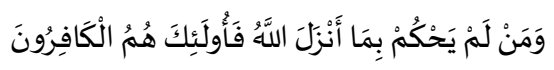

Dan barang siapa yang tidak memutuskan perkara kecuali dengan apa yang telah Allah turunkan maka mereka itu adalah orang kafir.

Kata yahkum dalam potongan ayat tersebut dipahami dengan "memutuskan" perkara atau "memerintah" tidak dengan hukum Allah adalah kafir, dalam arti keluar dari Islam. HTI tampaknya menolak pengakuan seperti Syeikh Nawawi yang memandang pengakuan terhadap hukum Islam hanya dalam hati saja sudah cukup, karena kesulitan menerapkannya di Indonesia yang berdasarkan Pancasila. ${ }^{30}$

Potongan Ayat lain yang juga disampaikan adalah QS AlMāidah [5]: 48:

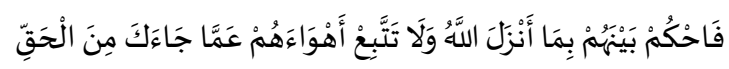

“...Maka putuskanlah perkara mereka menurut apa yang Allah turunkan dan janganlah kamu mengikuti hawa nafsu mereka dengan meninggalkan kebenaran yang telah datang kepadamu..."

Ayat ini juga dipahami sama seperti di atas, dimana untuk memutuskan suatu perkara haruslah dengan khilafah yang berkuasa secara menyeluruh. Tegaknya Daulah Khilafah adalah suatu kewajiban, dan kelalaian menegakkannya merupakan dosa besar. ${ }^{31}$ Mereka juga menyebut bahwa kematian seorang muslim yang tidak memberikan bai'at (kepada seorang Khalifah) merupakan kematian yang sangat buruk sesuai dengan hadits:

$$
\text { ومن مات وليس في عنقاه بيعة مات ميتة جاهلية }
$$

dan barang siapa mati, sementara tidak ada bai'at dipundaknya, maka matinya (dalam keadaan) jahiliyah. (HR. Muslim)

${ }^{30}$ Sukron Kamil, Laporan Penelitian Kompetitif Kolektif, Pola Keagamaan dan Bahasa: Studi Kontekstual Kata Serapan Arab dalam Teks-teks Keislaman Kontemporer (Jakarta: Universitas Islam Negeri (UIN) Jakarta, 2013), h. 74 .

${ }^{31}$ Hizbut Tahrir, Manifesto Hizbut Tahrir untuk Indonesia: Indonesia, Khilafah dan Penyatuan kembali Dunia Islam (tt: Hizbut Tahrir Indonesia, 2009), h. 14. 
Terpaku pada makna literal teks juga terlihat pada QS. AlNahl [16]: 89 yang mengungkap kesempurnaan al-Qur'an telah memuat segala sesuatu, serta QS Al-Baqārah [2]: 208 yang mengajak umat Islam untuk masuk ke dalam Islam secara kaffah (menyeluruh). Padahal semua hal berkenaan dengan persoalan sosial yang dimaksud dalam ajaran Islam hanyalah sebagai prinsip saja. $^{32}$

Ayat lain yang juga dimunculkan yakni:

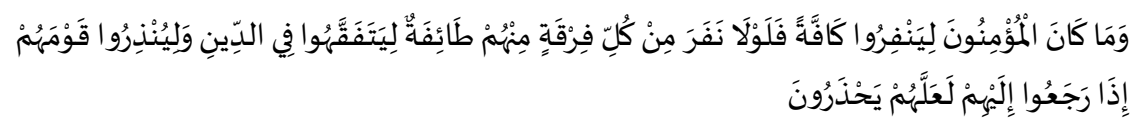

Tidak patut orang-orang mukmin keluar semuanya. Tetapi alangkah baiknya jika keluar sebagian (saja) dari tiap-tiap golongan dari mereka, supaya mereka menerima pelajaran tentang agama, dan untuk mereka mengingatkan pada kaumnya apabila mereka telah kembali kepada mereka, agar supaya mereka berhati-hati. (Q.S. alTaubah [90:122)

HTI menolak penafsiran diatas, bahwa kalimat "hendaklah dari setiap kelompok masyarakat ada golongan orang yang mempelajari ilmu agama, kemudian mereka kembali untuk mengajarkan ilmu tersebut kepada kaumnya" merupakan kesalahan. Mereka beralasan bahwa hukum syara' menegaskan agar setiap muslim yang baligh dan berakal wajib hukumnya memahami agama dengan kata lain farḍ 'ain bukan farḍu kifāyah. Karena tidak ada jalan lain agar, untuk mengikuti semua perintah dan larangan Allah tidak lain harus dengan mengetahui hukum-hukum syara' tersebut.

Ayat-ayat lain yang juga mendukung pemahaman mereka tentang wajibnya pendirian khilafah adalah pada ayat berikut:

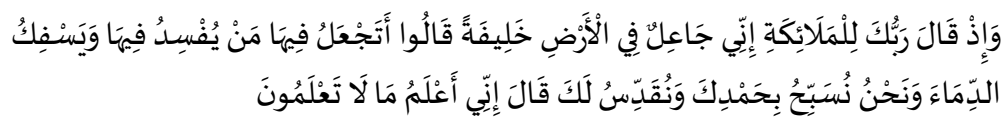

Dan (ingatlah) ketika Tuhanmu berfirman kepada para malaikat: "Sesungguhnya Aku hendak menjadikan di muka bumi itu seorang khalifah." Mereka berkata: "Apakah Engkau hendak menjadikan (khalifah) di bumi itu orang yang akan membuat kerusakan padanya dan menumpahkan darah, padahal kami senantiasa bertasbih dengan memuji Engkau dan mensucikan Engkau?" Tuhan

${ }^{32}$ Sukron Kamil, Laporan Penelitian Kompetitif Kolektif..., h. 74. 
berfirman: "Sesungguhnya Aku lebih mengetahui apa yang tidak kalian ketahui." (QS al-Baqarah [2]: 30)

Berdasarkan wawancara dari salah seorang pengurus HTI di Jambi menyebutkan bahwa HTI berargumen dengan ayat-ayat seperti di atas tentang penafsiran kata "Khalifah" yakni "Khilafah". ${ }^{33}$ Mereka beragumen berdasarkan pendapat dari alThabari. Artinya, al-Ṭabari menyebutkan bahwa Khalifah yang dimaksud adalah pengelola keseluruhan bumi, dalam artian sebenarnya. Mereka menolak pendapat-pendapat dari mufassir lain yang tidak merinci pemaknaan kata "khalifah" tersebut. Mufassir lain cenderung mengartikan kata "khalifah" sebagai pewaris bumi. Mereka menolak anggapan lain yang menyatakan bahwa masingmasing kita adalah khalifah.

Mereka juga memperkuat anggapan pentingnya berdiri khalifah atas dasar sejarah dimasa Rasulullah dimana para sahabat yang sibuk mengurusi kematian Rasulullah, lalu mengabaikan permasalahan umat pada masa itu. Mereka menegaskan bahwa dalam sejarah ini sangat jelas apa yang menjadi hal pokok dalam pembangunan Islam. Artinya, penentuan siapa yang akan menjadi khilafah atau pemimpin umat Islam pada masa itu merupakan hal yang sangat urgen. Hal ini menjadi ijma' dikalangan Sahabat dan menjadi hukum syari'at bagi kita sekarang. Mereka juga beralasan dengan prinsip "qiyas" dengan dalil kaidah kulliyat ( $m \bar{a}$ lā yatimmu al-wājib illa bihi fahuwa wājib).

Melihat kembali apa yang menjadi landasan pemikiran dari kelompok HTI adalah ketika ia menjadikan pendirian khilafah adalah kewajiban. Artinya, dikarenakan pendirian khalifah merupakan sebuah kewajiban, maka dari itu semua hal yang mendukung agar berdirinya khilafah juga merupakan kewajiban. Aturan-aturan tingkah laku misalnya yang telah disusun dan dijelaskan secara luas dalam bukunya "al-Nizam al-Ijtimā'i fi alIslām" atau berkenaan dengan hukum keluarga Islam dalam bukunya Mafāhim Siyāsiyah lihizb al-Tahrīr atau konsep pemerintahan yang akan dibangun baik pengaturan politik, militer dan ekonomi dijelaskan juga dalam karya al-Khilāfah al-Rașīdah al-Mau'ūdah wa al-Tahadiyāh.

\footnotetext{
${ }^{33}$ Wawancara dengan Fakhruddin (26 des 2014).
} 
Berdasarkan data-data yang telah diperoleh di atas tampak bahwa HTI merupakan organisasi yang bergerak atas dasar agama Islam dan tampak pula penafsiran serta pemahaman mereka cenderung tekstual. Namun demikian, di sisi lain HTI juga penganut paham kontekstual ketika mereka mengemukakan kewajiban berdirinya Khilafah. Mereka juga mengakui akan tidak adanya nașnaș yang secara tegas memerintahkan pendirian khilafah Islam, akan tetapi hal tersebut dapat dilihat dari makna tersirat dari naș, ijma' sahabat dan qiyas. Seperti pemahaman mereka yang menolak ijtihad kecuali berdasarkan naș-naș yang ada, serta tidak dibenarkannya menggunakan rasio di luar naș al-Qur'an ataupun hadis nabi.

HTI sebagai sebuah organisasi Islam juga memilik perbedaan dengan organisasi lain yang ada di Indonesia. HTI berbeda dengan NII (Negara Islam Indonesia) yang mengafirkan kelompok lain. Kelompok ini tidak mengklaim bahwa mereka yang paling benar. ${ }^{34}$ Kelompok ini hanya memiliki misi dan visi islami. Berbagai kelompok Islam di Indonesia tidak lantas menjadikan perpecahan dikalangan umat Islam. Prinsip kuat yang dibangun oleh HTI adalah "sikap mengintegrasikan antara urusan dunia dan agama adalah islami, sedangkan yang memisahkan keduanya itu tidak Islami". Artinya, HTI memandang bahwa benar dan salah itu telah jelas tidak bisa ditoleransi. Atas dasar ini pula HTI menolak kelompok JIL (Jaringan Islam Liberal) yang dianggap telah terpengaruh aliran barat dan sebenarnya merusak Islam.

\section{Penutup}

Gerakan-gerakan Islam yang menimbulkan banyak kegundahan dalam tindakan-tindakan mereka yang oleh beberapa pihak terkesan ekstrim tidak bisa menjadi alasan bahwa hal tersebut merupakan tujuan yang dianjurkan oleh al-Qur'an secara khusus atau Islam secara umum. Lebih tegasnya, gerakan-gerakan Fundamentalis Islam tersebut jauh dari kesan radikal, beberapa gerakan ini cenderung terbuka dalam menawarkan ide mereka. Hizbut Tahrir merupakan salah satunya, dimana mereka juga sangat mengecam aksi-aksi radikal yang terjadi di masyarakat

${ }^{34}$ Lihat Afadlal dkk, Islam dan Radikalisme di Indonesia ..., h. 278. 
mengatasnamakan Islam. Bisa dikatakan bahwa gerakan-gerakan Islam di Indonesia lebih moderat. ${ }^{35}$

Di sisi lain, penafsiran tekstual disebut-sebut sebagai landasan aksi-aksi tersebut. Tentu saja hal ini belum tentu semuanya benar. HTI secara umum memang menafsirkan al-Qur'an maupun Hadits secara literal teks, akan tetapi menggunakan penafsiran kontekstual dalam penerapan Khilafah. Artinya, mereka menafsirkan secara tekstual dan didalam prakteknya menggunakan penafsiran kontekstual. [ ]

${ }^{35}$ Ibid., h, 283. 


\section{DAFTAR PUSTAKA}

A. fadlal dkk. Islam dan Radikalisme di Indonesia, Jakarta: LIPI Press, 2005.

al-Nabhāni, Taqiyuddin, al-Nizām al-Ijtimā' $i$ fì al-Islām, pent. M. Nashir dkk. Jakarta Selatan: Hizbut Tahrir Indonesia, 2014

al-Nabhāni, Taqiyuddin, al-Takattul al-hizbī, pent. Zakaria, Labib dkk. Jakarta Selatan: Hizbut Tahrir Indonesia, 2013

al-Nabhāni, Taqiyuddin, Mafāhim Hizb al-Tahrīr, pent. Abdullah. Jakarta Selatan: Hizbut Tahrir Indonesia, 2007.

Fata, Ahmad Khoirul dan S Mahmudah Noorhayati, "Sekularisme dan Tantangan Tantangan Pemikiran Islam Kontemporer." Madania, Vol 20, No 2,2016.

Fata, Ahmad Khoirul, "Pembaharuan Hukum Islam dan Problem Otentisitas Agama", Ijtihad, Vol. 13, No. 2, 2013.

Fata, Ahmad Khoirul, "Kekuatan dan Kelemahan Tafsir al-Qur'an bi al-Sunnah", Farabi, Vol. 13 No 2, 2016.

http://id.wikipedia.org/wiki/Hizbut_Tahrir, diakses pada 12 Oktober 2014

http://www.mykhilafah.com/hizbut-tahrir, diakses pada 12 Oktober 2014

ICG Asia Report No 58 Osh/Brussels, Radical Islam in Central Asia: Responding to Hizbut Tahrir, ICG, 2003.

Kaltsum, Lilik Ummi, Mendialogkan Realitas dengan Teks. Surabaya: PMN, 2010.

Kamil, Sukron, Laporan Penelitian Kompetitif Kolektif, Pola Keagamaan dan Bahasa: Studi Kontekstual Kata Serapan Arab dalam Teks-teks Keislaman Kontemporer. Jakarta: Universitas Islam Negeri (UIN) 2013.

Mustaqim, Abdul, Epistemologi Tafsir Kontemporer. Yogyakarta: LkiS, 2010.

Saeed, Abdullah, Interpretating the Qur'ān: toward a contemporary approach. New York: Routledge Taylor \& Francis Group, 2005. 
Shihab, M. Quraish, Membumikan al-Qur'an: Fungsi dan Peran Wahyu dalam Kehidupan Masyarakat, Bandung: Mizan, 2009.

Siddiqui, Mateen, The Doctrine of Hizb ut-Tahrir, Conference Report The Challenge of Hizb ut-Tahrir: Deciphering and Combating Radical Islamist Ideology, The Nixon Center, 2004.

Syafrudin, U, Paradigma tafsir Tekstual dan Kontekstual: Usaha Memaknai Kembali Pesan Al-Qur'ān. Yogyakarta: Pustaka Pelajar, 2009.

Tahrir, Hizbut, Manifesto Hizbut Tahrir untuk Indonesia: Indonesia, Khilafah dan Penyatuan kembali Dunia Islam, Hizbut Tahrir Indonesia, 2009.

University, Oxford, Oxford Learner's Pocket Dictionary, Oxford University Press, 2008.

Wadud, Amina, Qur'an and Women: Rereading the Sacred Text from the Women's Perspektive, Oxford University Press, 1999.

Walters, Morgan L., The Holt Intermediate Dictionary of American English, New York: Holt, Rinehart and Winston, Inc, 1966. 